\title{
Marxian Approaches and Women's His- tory in Early Post-war Japan
}

\author{
Curtis Anderson Gayle
}

\begin{abstract}
During the early post-war period Marxian approaches to history in Japan sought to enfranchise women so that they might begin writing their own histories and become participants within the drive toward revolution. History writing was conceived as an existential activity and cultural practice that could help women and the working class become agents of socio-political change. A number of women's history-writing groups found such approaches useful and adapted some of the core methods about history writing originally developed in Marxian approaches between 1945 and 1955. By grounding their approaches to history in terms of 'local' and 'regional' spaces, however, these women's history writing groups would also differentiate their socio-political objectives from those espoused by Marxists concerned with 'national subjectivity' (minzoku jikaku). Instead, through emphasizing the role of inter-class and even inter-gender cooperation within specific representations of the 'local' and 'regional' these groups hoped that such approaches could become models for other women's history-writing groups. This paper will argue that Marxian approaches were both a source of inspiration and difference for such women's history-writing groups in Tokyo, Nagoya and Ehime.
\end{abstract}

\section{Introduction}

The development of local and regional women's history in post-war Japan can be understood within the larger context of Marxian approaches to history and social movements that dominated the political landscape during the 1950s. Put forward as a set of discourses and political practices that could 'awaken' and move the working class, Marxian history provided both opportunities and limitations for women interested in writing their own histories. During the early post-war period, history and history writing had become cultural practices that were broad enough to include women within their views of history and projects of socio-political change. As a result, the historical approaches developed by Marxists became a way of looking at history and social change that could benefit women and help legitimize history writing through the voices of women themselves. 
Whilst providing a radical and activist sense of history, Marxian approaches also came with their own inherent problems. This paper will first examine the structural logic of Marxian approaches to history in early post-war Japan and discuss the notion of 'national subjectivity' (minzoku jikaku) set forth within them. It will show that problems in this conceptualization made it necessary for those interested in writing women's history to separate themselves from the Marxian histories that had inspired them. The paper will then look at the development of three women's history writing groups - the Tokyo Women's History Research Association, the Nagoya Women's History Research Association, and the Ehime Women's History Circle - to draw out some of the methodological similarities and differences of such groups to Marxian approaches. The conclusion will suggest that although Marxian histories crafted during the late 1940s and early 1950s overlooked the concrete relationship of the individual to the nation whose (liberationist) subjectivity it had just conceived, they nevertheless furnished ideas about writing history that could be appropriated by those 'without voices' in Japan, particularly women.

\section{Marxism, Science and Radical Politics}

The idea of modern nationalism that ontologically resists and rejects the state is nothing new to intellectual history or theories of nationalism. Nationalism on both the left and the right has often taken umbrage at a state seen to be in collusion with ideologies, beliefs and systems deemed to be unhealthy or illegitimate. On the right, this has historically taken the form of ideologies that find the modern nation state to have compromised the 'purity' and historical salience of 'national life' - so that a state more befitting the nation is imagined and represented in histories and political narratives (Brown 1955). ${ }^{1}$ On the left, the radical tradition of twentieth-century Marxian thought (especially within anti-colonial movements) makes it clear that belief in a nation can be a valid political principle upon which to envision revolution and structural change (Forman 1998). ${ }^{2}$ In other words, the basic logic of anti-state nationalism is no stranger to modern political theory or cultural history.

During the early post-war period, a number of influential Marxian historians helped to produce an interesting amalgam of Marxism and nationalism within the context of Japanese historiography. Figures such as Ishimoda Shō, Uehara Senroku, Tōyama Shigeki, Eguchi Bokurō, Inoue Kiyoshi and Matsumoto Shinpachirō ${ }^{3}$ sought to make history a science by establishing basic principles $(k \bar{o} r y \bar{o})$ for the study of history 
within the Rekishigaku Kenkyūkai, or Historical Science Society (Rekishigaku Kenkyūkai 1946: 47). ${ }^{4}$ Such organizations consisted primarily of Marxian historians and, in 1946, they began conceptualizing history as an academic discipline which aimed to be independent of political concerns and based upon 'scientific truth'. By this, the Historical Science Society meant that the study of history should be written without any interference from the state or external forms of coercion upon historians. In order for such 'objective' history to be written in Japan, the Society insisted, historians would have to reject 'statism (kokka shijoshugi), the ideology of national purity ideas (kokusuishugi), militarism, fascism and warped ethnic nationalism (henkyō na minzoku shugi)' (Tsuchiya 1946: 56-9). Similarly, the new principles also asserted that the writing of history could enlighten ordinary people toward a more pronounced sense of historical consciousness only if the terrain of history were kept free from external ideologies and forms of politics. Even though Marxian thinkers and movements had at times been able to distance themselves from such external forces during the 1920s and 1930s, the Society maintained that history had not been fully independent of the state during the pre-war years. The now 'objective' study and writing of history would, conversely, be proclaimed as something completely 'new' to the Japanese social and cultural landscape after the war.

This meant that the study and writing of history were to become things that could unite, rather than divide, historians from the public at large. As Eguchi Bokurō - an influential figure within the Historical Science Society and a major force in early post-war Marxian history - surmised, the failure of pre-war Marxian history during the Taishō period (1912-26) had been partly due to its very 'limited connection' to 'mass movements' that had sought to change Japanese society (Bandō 1976: 292). By combining the idea of 'historical science' (rekishi kagaku) with the notion of a transition in Japan from state capitalism to socialism through revolution, moreover, Eguchi and his colleagues at the Society sought to create a historical and epistemological space for the working classes to take part in future historical change. ${ }^{5}$ This is precisely what the historical principles of 1946 were referring to when they stressed the need to pursue history as an independent academic discipline by thinking seriously about the 'correct relationship between historians and the people (jinmin)' (Rekishigaku Kenkyūkai 1946: 47).

Those most active in writing histories through the lens of the nation (minzoku) belonged to the Historical Science Society and the Democratic Scientists' Association. ${ }^{6}$ They were more or less in agreement as to the 
necessity of writing new kinds of histories that might better articulate how conceptions of the nation in Japan could become something politically progressive (and therefore acceptable) in the aftermath of the war. Given that wartime thinking on the nation had been discredited in public memory after 1945 (Gluck 1995), coming up with new ideas and representations of the nation would be no easy task. Thus, Marxian thinking on the nation, in order to become a public discourse accepted by the working classes at which it was aimed, sought to ground its methodology within the larger idea of the study of history that was undergoing tectonic shifts during the late 1940s and early 1950s (Gayle 2003). By articulating their ideas about the nation through the new sense of history as a science, it would be possible for Marxian historians like Eguchi, Ishimoda and Inoue to present their approach as something politically necessary.

Marxian historians and thinkers were also becoming acutely aware of the need for more concrete and explicit answers to questions of subjectivity and independence, given political developments in Japan and East Asia by 1950. In addition to the oppression of labour unions and retractions of promises that post-war democracy in Japan would enfranchise those who had been denied voices in the past, the advent of socialism in Mao's China and conflict on the Korean Peninsula were seen by many as jeopardizing the chances for revolution to take hold. In response, Marxian historians like Eguchi would formulate the idea that Japanese culture could be understood in terms of an historical trajectory other than that of 'bourgeois modernity' or liberal democracy (Eguchi 1974). Similarly, Marxian thinkers such as Kurahara Korehito ${ }^{7}$ also put forward the notion of 'cultural struggle' as the basis for working class-consciousness and political change, just at the moment that the 'Reverse Course in Occupation' policy was making a flagrant mockery of the ideals of post-war democracy.

Rather than emphasizing economic problems that affected the working classes, Kurahara claimed that by mediating the notion of class struggle with the 'construction of an advanced form of national culture' (minzoku bunka) based upon the history of the working classes (rather than upon bourgeois culture), it would be possible to attain greater heights of political resistance and change (Kurahara 1948: 62-73). In so arguing, he hoped to link the dynamics of class struggle with ideas about Japanese culture as the domain of everyday working-class life so that class-consciousness might be conceived as something more than a simple 'material' issue. This kind of synthesis suggested that just as it was possible to offer economic/materialist alternatives to serve the 
working classes (e.g., socialism as an alternative to capitalism), so it was possible to substitute reactionary and bourgeois ideas about culture with new approaches that linked it to working-class identity and history. Japanese culture, in this analysis, did not have to be a pure function of capitalist consumption or politics. ${ }^{8}$

Following these ideas, Ishimoda and Marxian historians during the early 1950s offered a conception of revolution as something far more profound than the mere substitution of one mode of production with another (i.e., socialism for capitalism). Ishimoda and like-minded historians instead grounded the idea of revolution upon the notion that culture/everyday life did not necessarily have to support middle-class life and the capitalist state. By rejecting two extreme sets of explanations about historical change - either that it could be understood purely in terms of economic considerations, or that it could be realized through the kinds of ideologically clad appeals to 'national identity' that had been prevalent in pre-war Japanese nationalism - Ishimoda believed that revolution might be expressed as a change in the way the working classes thought not only about class, but also about questions of identity that spoke to historical memory and cultural identity in modern Japan.

It was in fact the pre-war Italian Marxian thinker Antonio Gramsci who first put forward this sense of the working class developing their own ideas and values against bourgeois cultural dominance. Gramsci had suggested that the working class could gain liberation only if they could first establish their own 'original conception of the world' from the starting point of culture (Pozzolini 1970: 109) Yet, even though Gramsci's ideas were known to Marxian thinkers in Japan such as Kurahara and to historians such as Ishimoda, the early post-war sense of working-class agency was also heavily shaped by conceptions of history writing - as an existential tool for socio-political change - that pervaded Marxian approaches to history during the late 1940s and early 1950s. Whilst it is therefore instructive to reach back to Gramsci to understand the basic idea of how revolution has been conceived as more than just a 'material' affair, in the early post-war Japanese case, new ideas about history and its relationship to the working class constituted an important part of thinking about how culture might underlie political change.

\section{Historicizing the Transparency of the Nation}

How could something that claimed to be 'scientific' - only several years after the conclusion of the Second World War - also style itself as a set of discourses and ideas that sought to consolidate Japanese 'national con- 
sciousness' (minzoku ishiki)? By couching the language of history within new claims to historical science made by Marxian historians, it would become possible to rationalize a new kind of ethnic nation that actually conformed to progressive ideas of history in Japan. The old idea of the ethnic nation based upon metaphysical attributes of Japaneseness, such as 'blood' and the imperial house, was replaced with a new vocabulary of historical constructionism that depicted ethnic nations in the modern world as the product of pre-capitalist and capitalist development on the road to socialism (Gayle 2003). These ideas about both the nation and history were crystallized in Ishimoda's 1952 two-volume work Rekishi to Minzoku no Hakken [The Discovery of History and the Nation], which represents perhaps the most important single work within Marxian history during this period (Ishimoda 1952).

What might have therefore have seemed a polarity between 'science' and 'national consciousness' was reconciled through an emphasis upon the fact that the Japanese state had not yet reached the stage of socialism or communism. In order to rectify this problem, Marxian historians put forward histories in which democracy and capitalism were seen as epiphenomena to be politically invalidated by exposing the failures of the post-war state in Japan. In contrast to 'bourgeois democracy', which was now viewed as the handmaiden of American imperialism, for example, Marxian history argued that only Soviet-style socialism was a truly democratic ideology that could work for Japan (Ichikawa 1949: 24-35). ${ }^{9}$ Thus, both democracy and capitalism were treated as accoutrements to 'bourgeois modernity' which had to be ultimately rejected as impediments to revolution (Eguchi 1974: 161). As some have noted, these views were very much influenced by the 1950 Comintern critique of Japanese capitalism, which urged Marxists to abandon initial post-war attempts to bring about revolution in cooperation with the American Occupation and parliamentary democracy. In its place, Moscow had urged a more militant strategy by which Japanese Marxists might gain the support of the working classes and make a direct transition to socialism (Napier 1952: 12-13). ${ }^{10}$

Although the Soviet origins of Marxian thinking on the nation were historically important to a good number of Japanese Marxists during this period, the politics of this history also involved the recently minted example of Mao Zedong's China. In particular, Ishimoda Shō and Saitō Akio held up China's wartime resistance to Japan as a model for 'campaigns of the people' seeking 'cultural unification' against occupation and imperialism. The purpose of this very effective discursive twist was 
to replace China's past with Japan's present, and Japanese colonialism with American imperialism, so that China's wartime struggle to raise a 'minzoku tōitsu sensen' (national unification front), might be reproduced in Japan during the 1950s. As Ishimoda surmised, whilst both China and the Soviet Union were to play a didactic role in Marxian history, China was to serve as the premier case-study for Japan since it illustrated the successful 'transplanting of socialism onto Asian soil' (Saitō 1953: 14041), in effect making Mao's China something more relevant to Japanese Marxism than the existence of Stalin's Soviet socialism.

Yet, Stalin's theory of the nation was still relevant to Japanese Marxists during the late 1940s and early 1950s. Stalin argued that the process of history revealed the progression of peoples from enslavement to liberation, subjugation to conquest, and from inconsequential self-consciousness to a profound realization of one's place within a national grouping that was independent, modern and ultimately socialist. As Stalin surmised in his Marxism and the National and Colonial Question and reaffirmed in his Concerning Marxism in Linguistics, a nation was a 'historically constituted, stable community of people, formed on the basis of a common language, territory, economic life, and psychological make-up manifested in a common culture' (Stalin 1935, 1950). Among Marxian historians in Japan, this idea of national development was treated as the very opposite of pre-war bourgeois nationalism, militarism or fascism, in that it made no claims to the metaphysical origins, or ontological inevitability, of national existence. ${ }^{11}$ Rather, the historical evolution of the Japanese people was what had ultimately come to shape its specific character, history and politics. By accepting this logic, moreover, historians such as Ishimoda, Inoue and Eguchi were able to argue that the nation was 'natural' and transparent, on the one hand, and that it was also something contingent, ever-changing and ultimately radical, on the other. ${ }^{12}$

It would be a mistake to assume that this idea of the nation completely ruled out the legitimacy of the Japanese state. On the contrary, Marxian history focused upon what kind of state might be most appropriate for the political activity conceived in conjunction with new ideas about the nation. Historians such as Eguchi Bokurō, along with Ishimoda, viewed the existence of ostensibly multi-ethnic nation states in the Soviet Union and China as shining examples of how, under a non-coercive form of socialist 'multi-culturalism', these societies had successfully and permanently united peoples of different nationalities into one class, nation and indeed state (Eguchi 1957: 91-101). Given that they saw Japan as a place that had 
relatively no significant ethnic-minority populations, they also reasoned that there would be far less of a problem raising a unified consciousness of the nation in Japan than had been the case in China or the Soviet Union, even though they provided no detailed plans as to what conceptions of citizenship they preferred for their anticipated socialist state. ${ }^{13}$

In other words, just as their historical rejection of capitalism and postwar democracy was provisional - in that true democracy would come under socialism - so their ontological rejection of the Japanese state was also contingent upon the possibility of a more sophisticated political entity coming to fruition through revolution. ${ }^{14}$ Of course, this does not mean that Marxian historians were operating under the influence of some reflex impulse for a strong Japanese state (sokoku), a contra-claim recently made by Oguma Eiji (Oguma 2002: 298). It might be more accurate to instead suggest that by envisioning a new political order based upon the transition to socialism, some Marxists hoped to make the possibility of successful class struggle seem more convincing and thereby offer a viable social and political solution to the problems of the early post-war period.

As an historical approach, such ideas were quite visionary - all the more so given that so shortly after the war, such specific representations of national identity could be offered as radical solutions to the problems associated with democratic reconstruction and modernity. In fact, no less an authority than the political thinker Maruyama Masao had declared in 1950 that the resurgence of any form of 'healthy' Japanese nationalism would be unlikely in the foreseeable future. Maruyama maintained that any viable Japanese nationalism would demand nothing less than a completely different 'sense of mission' in order to win over the public in the aftermath of Japanese imperialism and fascism (Maruyama 1964: 159, 166). Owing to what he saw as 'remnants of the old feudal structure in Japanese society' and fresh memories of Japan's attempts to create a Greater East Asia Co-Prosperity Sphere, Maruyama was convinced that within Japan and East Asia any attempts made to frame Japanese nationalism as something 'healthy' and progressive were doomed to failure, even though he ultimately saw the 'happy marriage of democracy and nationalism' to be something that would help reconsolidate and legitimize Japanese modernity somewhere down the road (Maruyama 1976: 294).

There were several techniques by which Marxian history and thought sought in essence to prove Maruyama wrong. The most dramatic and appealing means by which historians such as Eguchi, Ishimoda, Inoue, 
Toyama and Matsumoto attempted to convince the public of the viability, and indeed political necessity, of new thinking about the nation was by grounding Japanese history within the modern tradition of Asian liberation nationalism. By presupposing and narrating the Japanese nation, or minzoku, as colonized by the post-war state, Allied Occupation, and global capital, it would be possible to posit both the rightful existence of national consciousness as well as the obfuscation of that consciousness by the same basic geo-political forces against which peoples had - and were - struggling in China, Korea, India, Indonesia, Africa and Latin America. The idea of liberation became the anvil upon which this new mission could be hammered out not only as a national and cultural struggle, but also as one link within a much broader and deeper movement to resist American and European domination of Asia and the Third World (Uehara and Munakata 1952: 176-77). ${ }^{15}$ By discarding bourgeois modernity (but not 'modernity' per se), then, Marxian historians hoped to realize a new 'post-colonial modernity' that was liberationist, socialist and primarily Asian in origin.

One problem with this epistemological tweaking of history lay in the fact that Japan had a past to account for in Asia. By holding up China as historically, socially and politically ahead of Japan it was, however, possible to rationalize away some of the guilt that must have remained over the failure of the left to prevent war with China. More practically speaking, through the example of Mao's China, Japanese Marxists could make history something that had appeal to the working classes. This was because China had already achieved what Marxists were striving for in Japan. So heavily did the example of Mao's China weigh for Marxists in Japan that during the late 1950s, as Marxian historians began to rethink their strategies, Ishimoda himself lamented that part of the reason for not being able to bring about revolution could be attributed to an overreliance upon the way revolution was forged in wartime China against the Japanese. He maintained that not enough thought had been given as to how revolution would need to fit the Japanese context (Ishimoda 1990: 366, 378).$^{16}$

\section{'National Subjectivity' (Minzoku Jikaku) and its Shortcomings}

The centrepiece of this overall approach to Japanese history lay in the notion that the masses could be moved to action through history writing - history was seen as a means to help bring about the 'subjectivity' of the working class. The raison d'être of the People's History Movement (Kokuminteki Rekishigaku Undō) spearheaded by Marxists like Ishimoda 
lay in making history writing an instrument through which ordinary people might 'awaken' to their historical condition and engage in political struggle (Gayle 2003: 131-36). ${ }^{17}$ Whereas pre-war attempts to deprofessionalize and popularize the writing of history were limited to small-scale movements such as the Seikatsu Tsuzurikata Undō (How to Write Your Daily Life Movement) 'directed at working class children' as part of an effort to 'combat the excesses of nationalistic moral indoctrination' (Figal 1996: 907), Marxian history now operated under the assumption that the complete de-professionalization of history writing could bring about a change in popular consciousness that might unlock popular desires for self-representation and liberation.

To these ends, the Movement organized a number of different forums through which history writing might become a practice embedded within the lives of the ordinary working class in Japan. Through history writing, cultural campaigns and activities supported by local branches of Tokyo-based organizations, the Movement encouraged intellectuals and students to venture into local areas of Japan and work with labourers, housewives and ordinary people to write their own histories. Women and workers in villages, factories and farms began to write about their experiences and their pasts, becoming increasingly aware of how their subjective life-histories collectively constituted what became known as a 'national subjectivity' (minzoku jikaku) which carried within it the potential to transform Japanese society. Both individual history writing and writing in 'circle' groups were encouraged as part of new commitments to make historical science work towards revolution with far greater autonomy from the state than had been possible in the pre-war period.

For Marxian historians in Tokyo and Kyoto, history writing by the working classes was not merely to be done in and for itself. Rather, it was seen as an exercise that carried with it the potential to recover and redeem cultural practice in everyday life as something essential to the project of 'national subjectivity' (minzoku jikaku). Writing histories that could serve as examples to ordinary people interested in doing the same, Marxists thought that if the working classes could be convinced that they were the agents of political change, history could be confirmed as the possession of ordinary people and not just intellectuals or professional historians. Yet, the notion of 'subjectivity' here was not explicitly grounded upon the existential consciousness of rational individuals who possessed free will and social choice. The national subject of minzoku jikaku, or awakening, was instead mediated by the politics of class uni- 
fication and revolution. Concrete realizations of individual conscience were not to be woven through vigorous opposition and engagement between the individual ego and group interests. The autonomy and independence of the Japanese ethnic nation could only come to fruition through a form of self-consciousness whereby each Japanese saw him or herself as 'organically related' to one another (Uehara and Munakata 1952: 136-37). Existential concerns and individual consciousness were, therefore, seen as important primarily to the extent that they served the historical idea of the nation and the political promise of a socialist state. In this sense, individual subjectivity and the autonomy of groups on the margins of Japanese society - women, to take one example - were subordinated to the narrative of class unification. Such was the case even though conceptions of class were informed by flexible notions of 'revolutionary culture' (kakumeiteki bunka) as conditions for radical political change (Matsumoto 1956: 167).

What Marxian history lost in terms of individual subjectivity within 'national subjectivity', however, it made up for in thinking about history itself. In fact, it would be fair to say that the approach to history developed through Marxian discourses between 1945 and 1955 was in the larger scheme of things relatively successful. Contrary to selfimposed criticisms of early post-war Marxian representations of the nation (Oguma 2002: 349-50), it is unnecessary to relegate all of it to the 'dustbin' of post-war Japanese history. This is because one of the central objectives surrounding the project to rehabilitate thinking about the nation involved de-professionalizing history so as to transform it into something that could be directly undertaken by women, the working class, outcastes and others on the margins of Japanese society. In other words, even though thinking about the nation in Marxian history predicated individual subjectivity to class-based interpretations of political change, Marxian approaches also provided something that would become methodologically useful to groups interested in resisting various forms of hegemony, including some aspects of Marxian discourses themselves.

\section{Inoue Kiyoshi and 'the History of Ordinary Women'}

Although Marxian history as a political discourse did not gain the hegemony it needed during the 1950s to produce a socialist revolution, it was successful in sparking the development of women's history groups in places like Tokyo and Nagoya from the mid-1950s. Such groups were in fact the very kind of voiceless minorities whose participation was 
sought by Marxian historians and the People's History Movement. In this sense, then, there was a very subtle but important irony at work: whilst appropriating new thinking about history as a de-professionalized and 'existential tool' for individual and social growth, some women's history groups sought to challenge the sense of subjectivity embedded within Marxian history. Although borrowing and refining these views about the relationship of history writing to socio-political change, women's history-writing groups also sought to create their own spaces and discourses that brought to life different concerns from those being developed by male historians in Tokyo and Kyoto.

In order to map the coordinates of such approaches and discourses, it is first necessary to point out how women and women's history became the active subject of Marxian thinking and how this was tagged on to quintessentially Marxian views on liberation. In keeping with the early post-war promise of Marxian history to focus on the lives and problems of ordinary people and the working classes, Inoue Kiyoshi's $1949 \mathrm{Ni}$ hon Joseishi [The History of Japanese Women] engaged the subject of Japanese women, from ancient to modern times, through the 'principle subject' (shujin) of the 'Japanese proletariat' (nihon jinmin) so that he could ultimately write a 'people's history' (jinmin no rekishi) of women in Japan. Conversely, Inoue took aim at previous attempts to write women's history as having for the most part ignored gender relations in favour of writing 'histories by a few male elites who dominated ordinary people' so that 'histories of Japanese women' amounted to little more than 'love stories' centring around well-known figures (Inoue 1949: 1-2). Rather than looking to 'the imperial elite', 'the nobility' or 'women from illustrious bushi families', Inoue chose instead to emphasize the 'real lifestyles' (jitsu seikatsu) of Japanese women (Inoue 1949: 2-3).

In a very concrete sense, Inoue helped to create a space within postwar Marxian historiography for 'the history of ordinary women' (jimin josei no rekishi). At heart, Inoue saw women's history in a Japan striving towards socialism as needing to focus upon the struggle of women towards 'liberation' whilst also 'treating women as autonomous independent' human agents (Inoue 1949: 2-3). Even though the subjectivity of women (and their historiographical inclusion) was predicated on this sense of liberation, the methodology being developed by Inoue and his colleagues did encourage women to begin writing their own histories. Indeed, Marxists like Inoue were aware that their methodology would have to incorporate the everyday lives and struggles of those on the margins of Japanese society and the gains being made by women within 
the women's movement. Conversely, women's history-writing groups to emerge in Tokyo, Nagoya and Ehime have made it clear that they were very much involved with the women's movement and were influenced by Inoue's 1949 text. ${ }^{18}$ Yet, each of these groups - though influenced by Marxian approaches to history - sought in different ways to contest the notion that their emancipation depended upon class unification and national liberation.

\section{Writing Women's History in the Centre (Tokyo)}

The Tokyo Women's History Research Association (Josei-shi Kenkyūkai) was originally established in 1946 as a subsection of the Historical section of the Democratic Scientists Association (Minshushugi Kagakusha Kyōkai no Rekishi-bukai). The latter was a driving force behind the conceptualization and organization of the People's History Movement during the 1950s, to which historians such as Ishimoda Shō and Inoue Kiyoshi belonged. The Tokyo Women's History Research Association was headed by activists such as Tatewaki Sadayo, who had worked during the Taishō period for the National Women's Alliance (Zenkoku Fujin Dōmei) and had opened a school for women factory workers in Tokyo during the 1930s (Mitsui 1959: 183). The Tokyo group also consisted of working women such as Ide Fumiko, Murata Shizuko, Mitsui Reiko and Nagahara Kazuko. ${ }^{19}$ The fact that this group dates back to the immediate aftermath of the war also suggests that women were very quick to realize that history was becoming a tool by which those previously disenfranchised might create the means to a greater sense of subjectivity. Mirroring developments within Marxian history during this period, moreover, the Tokyo Women's History Research Association defined its goals not merely in terms of social activism on the one hand, or historiography on the other hand. Instead, it defined its objectives by looking at how labour, activism and historical theory might be brought together so that women could write their own histories and from this space also join movements seeking social and political change.

The Tokyo group had much in common with Marxian approaches to history being honed during the late 1940s. For instance, Ide Fumiko recalls that she and the entire group believed that 'historical science' (rekishi kagaku) would provide the opportunity for new thinking about the role of women within Japanese society and new 'laws of history' (rekishi no hossoku) would help ensure dramatic change for women (Ide 1976: 115). ${ }^{20}$ This process, as described by the Tokyo group, began with 'individual subjectivity' (kojinteki jikaku) and progressed to 'economic 
independence', organization among labourers (in line with Inoue Kiyoshi's ideas about the role of women within a liberating proletariat), and finally social transformation (shakai henkaku). The process was collectively known as the 'rules for the liberation of women' and whilst not specifying socialist revolution as the concrete form of social transformation sought by women, it did share Marxian ideas about history and historical progress. After all, new approaches to women's history 'like other branches of historical scholarship' that were acknowledged as legitimate historical enterprises were very much influenced by both Marxian 'historical scholarship and liberation theory' (Germer 2003: 4). This is why Ide recalls that Inoue's approach to the history of Japanese women was nothing short of 'electrifying', even though she and her colleagues wanted to 'overcome' Inoue Kiyoshi's approach with something more appropriate for women themselves by grounding the notion of subjectivity within the histories and activities of individual women themselves (Nagahara 2003).

In other words, Ide and the Tokyo group wanted to distance themselves from Marxian attempts to define liberation solely in terms of class. To be more specific, Ide maintained that Inoue's approach made the mistake of 'reconstituting Japanese history through the historical materialist view of history carried over from the wartime period'. Here, Ide suggested that the 'liberation view of history' (kaiho shikan) Inoue incorporated into his idea of class was at odds with the needs of Japanese women as new citizens in post-war Japan (Ide 1986: 157). Her critique of Inoue was not, however, based upon a rejection of his notion of class, per se, but instead upon how women were conceived within this notion of class and how their subjectivity was contained and framed within the larger trope of class agency (consciousness) as the motor of political change. Thus, even though for Ide the methodology and principles of Marxian approaches were useful for Japanese women and for encouraging women to begin writing their own histories, the liberation of women remained wedged within the narrative of working-class emancipation from capitalism and the end of the capitalist state in Japan.

Tatewaki Sadayo put her objections into action by asserting that the liberation of Japanese women would have to involve the unification and cooperation of all women regardless of their class or status. It was from this standpoint that her 1957 publication Nihon no Fujin [Japanese Women] argued it would be necessary to bring women of different stripes together beyond the limitations of class (Koike 1981: 106). Tatewaki believed that liberation as Marxists had framed it ignored the realities 
of everyday life for women in Japan. Yet, she also lamented that many women still thought 'women's emancipation' would come automatically through class struggle rather than through the coordinated efforts of women's organizations and movements. Adherence to the Marxian view of class and revolution had, quite ironically, produced what Tatewaki called an excessive concern with 'direct material threats posed to oneself and one's family' rather than true gender-based cooperation and activism (Tatewaki 1957: 207-9).

If we focus our attention on historical methodology and principles, however, it becomes clear that the Tokyo group found many useful things within Marxian approaches. For instance, in keeping with the spirit of history writing propounded by Inoue, Ishimoda and others, the Tokyo group saw history as something that they could themselves engage in, even though they were not trained academics or historians. As part of the Marxian principle of combining textual study/reading with social activism, members wrote their own histories and the histories of groups such as Japanese women, labourers and farmers. They also conducted surveys of factories and villages and even sponsored a 'Conference for Working Women' (Hataraku Josei no Tsudoi) which focused upon problems related to labour unions and working conditions for women; indeed, the Tokyo group was very much tied into the women's movement (Ide 1976: 116). Much like the Democratic Scientists' Association (organized by, among others, Inoue and Ishimoda) through which it was founded, the Tokyo group went to villages and factories in order help ordinary people write their own histories and to better understand the problems of women in local areas. In terms of principles, methods and themes, then, the Tokyo group put to work the more practical aspects of Marxian approaches for the benefit of Japanese women. Some have even postulated that the Tokyo group was so embedded within Marxian approaches and the People's History Movement that their work 'positioned the history of the post-war women's movement within the [Marxian] general narrative of Japanese history', in effect returning women's history to the place from which it had originated (Koike 1981: 106).

\section{Women's History as a Local Concern in Nagoya}

Local women's history-writing groups such as the Nagoya Women's History Research Association would depart from this kind of history writing by positioning their accounts in spaces apart from the general narrative of Japanese history. The Nagoya Association, originally founded in 1959 
by a group of women from the Asahi Women's History Circle (founded in 1955), was less concerned with Marxian views of liberation and more interested in how pre-war liberation movements like the Blue-stocking Movement could be related to events taking place in Nagoya, rather than to those taking place in the centre $(\operatorname{ch} \bar{u} \bar{o})$. Marxian views on history were therefore not as important as developing and writing histories that could 'bridge the subjective awareness of their lives and activities' with those of their mothers and grandmothers in Nagoya (Nagoya Josei-shi Kenkyūkai 1969: 44). The Nagoya group was convinced that such an approach was necessary to lead to the development of what might be called true 'local women's history' (kyōdo josei-shi) and the emancipation of local women in Japanese society (Nakayama 1992: 60).

Much like the Tokyo Women's History Research Association, the Nagoya Women's History Research Association took careful exception to the way Marxian history had framed womanhood as ultimately an issue of class. They contested the notion that women's history in Japan could properly be written by men, since male experiences and views of society came from a different habitus and set of experiences. This was indeed a feature very prominent in both the Tokyo and Nagoya groups. Yet, whilst the Tokyo group did not directly contest the representation of women contained within the historical struggle of women for liberation in Japan, as put forth for instance by Inoue Kiyoshi, members of the Nagoya group sought to develop their own sense of womanhood intersected by local history and local struggles for economic, social and political enfranchisement. The creation of local women's history thus represented a historical space in which womanhood stood as a local issue of the past and present and not an axiomatic subject proscribed by grand narratives of structural change.

Just as in the relationship between Marxists and the Tokyo Women's History Research Association, there were also points of both inspiration and divergence between the Tokyo and Nagoya groups. In fact, it was through an article in the women's journal Fujin Gahō [Portraits of Women] about the Tokyo group that women in Nagoya belonging to the Asahi Circle became interested in forming their own organization. Although inspired by the Tokyo group, the Nagoya women wanted to write women's history that would be pertinent to women in Nagoya and that could speak for local women (Itō 1995: 316). As original member Nakayama Yasuko notes, the Nagoya group set out to write its own women's history in terms of local (kyōdo) issues in the hope that this local practice would be followed by women in other areas of Japan (Na- 
kayama 1966: 90). In other words, the writing of women into history had progressed to the writing of Japanese women's history by women, and subsequently to the writing of local women's history that could separate women's history from sweeping generalizations about gender and the nation contained in Marxian depictions of political change.

In histories being written by women, moreover, the space of the local was becoming a site within which subjectivity could be produced in ways contrary to Marxian approaches. No less a figure than Murata Shizuko of the Tokyo Women's History Research Association recognized that the history being written by women in Nagoya was truly 'local women's history' and was, therefore, something different from the women's history being written by herself, Ide, Mitsui and Tatewaki in Tokyo (Murata 1969: 44). The Nagoya group proved that the idea of the local could actually work as a space within which to seek out greater autonomy and cooperation in ways not beholden to class or system-wide (national) change. For members like Nakayama Yasuko, this meant that women in post-war Nagoya would have to look consciously at how women in local communities had overcome difficult historical conditions in the past. According to this view, women in local communities such as Nagoya would also have to ground their history writing in 'scientific thought' (kagakuteki shikō) in order learn about the past and bring about peace in the present (Nakayama 1966: 89).

It was nonetheless also true that history written by women in local domains and by local voices was a concept not completely divorced from Marxian approaches - there was much from Marxian histories that had influenced the Nagoya group. Just as in the People's History Movement and in Tokyo, history in Nagoya was seen as more than the reading of documentation, and could include, for instance, oral histories with women who had taken part in pre-war movements in Nagoya. In this vein, members of the Nagoya group such as Nakayama wanted to 'study history by their own hand' and hoped to utilize 'historical research' as a 'necessary part of women's liberation'. This was an idea that was first expressed by Mitsui Reiko in the Tokyo Women's History Research Association in the 1950s and provided the spark that ignited the creation of the Nagoya Association (Nakayama 1992: 55). Here, the links between Nagoya and Tokyo were undeniable. As much could also be seen in the idea that 'scientific history' (a concept derived from Marxism and put forward by the Historical Science Society in 1946) could legitimize the interdependence of history and social activism, especially within the belief that history writing could serve the cause of peace 
and international cooperation. In terms of historical methodology and principles, the Nagoya group (like its Tokyo alter ego) owed much to Marxian historical approaches even though they differed about the site (national vs. local) and telos (national liberation vs. local emancipation) within which such approaches might be utilized.

\section{From Local to Regional Women's History (Ehime)}

During this period another important women's history-writing group would emerge, namely the Ehime Women's History Circle. Unlike the Tokyo and Nagoya groups, its members consisted of both women and men who were involved in regional (Ehime Prefecture) education and labour unions. Formed in January 1956 with the close assistance of the Modern History Institute headed by the Marxian historian Shinozaki Masaru, ${ }^{21}$ members of the group feared for the future of democratic education in Ehime and saw history as one means by which to improve both their own awareness of historical issues in Ehime, as well as their potential to change society and politics. From its inception, the group consisted of ordinary workers, businessmen, students and housewives (Ehime Josei-shi Sākuru 1986: 20), thereby reinforcing the hypothesis that the Circle was interested in gender unity and interclass cooperation rather than gender-exclusive activity (as in Tokyo and Nagoya) or working-class unification (as in Marxian approaches).

The Circle also sought to write the history of women and others in Ehime Prefecture in ways that stood out from other approaches. The fact that Kawamata Yoshiko ${ }^{22}$ and other founding members had as one of their objectives the study of Marxian history suggests that one purpose of the group was to study and ultimately to write history. At the same time, however, the group believed one way to go about this was by writing regional women's history in Ehime Prefecture and incorporating new historical knowledge into their perspective. Whilst historical methodology and the reading of Marxian histories were important items on their agenda, the founding members of the group also believed that regional women's history would be an especially worthwhile space from which to connect new historical methodologies in Japan with the concerns of women in Ehime. By studying Marxian approaches, members of the group hoped to be able to bring this knowledge into practice in Ehime primarily, but not exclusively, through the efforts of women.

As early member Kumito Fujiko ${ }^{23}$ notes, 'whilst trying to improve the lives of women in Ehime', the Circle 'studied historical texts' with the assumption that 'the writing of women's history could become one 
important dimension to the Women's Movement' in Ehime (Ehime Josei-shi Sākuru 1986: 53). For members of the Circle, history writing also 'represented a move away from "war education" (senso kyōiku) and statist views of history' (koku shikan) to instead 'place ordinary people in the centre of history' (minshu wo chüshin ni suru rekishi). Much like the methodology of Marxian approaches, this view assumed that history should not merely be an object of study that would speak to ordinary people but rather a device through which ordinary people could find their own voices and go about changing the spaces in which they lived. Utilizing history in order to do this was something advanced by Marxian historians such as Uehara Senroku, Matsumoto Shinpachirō and Inoue Kiyoshi, all of whom served as both an inspirational models and personal contacts of Circle members from the very outset (Ehime Josei-shi Sākuru 2003).

It was against this background that the Ehime group very early on decided to study Inoue Kiyoshi's 1949 Nihon Joseishi [The History of Japanese Women]. They were, however, adamant that they would not 'listen to lectures' by professional historians as the 'basis of their study'. Even though Inoue wrote women's history 'from a women's viewpoint', there was also a perception among Circle members that 'history should not be written by elites' (erai hitotachi), whether male historians like Inoue or the wives of professional historians and intellectuals such as Nagahara Kazuko and the Tokyo Women's History Research Association. On the contrary, they maintained that 'each person should write his or her own history' (Ehime Josei-shi Sākuru 2003).

The study and practice of writing regional history could, in other words, enable women and others to find their own voices without subordinating themselves to larger institutions or professional authorities. Thus, the conscious decision of Circle members to include different classes and genders within their new history writing and activism reflected the conviction that history would have to be both 'scientific' and 'objective' whilst at the same time providing a way to locate both 'individual member' and 'group' subjectivity (jikaku) within local and regional society (Ehime Josei-shi Sākuru 2003). In this sense, the beliefs of the Circle fit quite well with the need to develop conceptions of local and regional history that included women, but that also opened up the possibility of a larger and cross-gender/cross-class inclusion of those whose voices had long been denied by official histories and local histories, even Marxian histories. The subjectivity of women (and others in Ehime Prefecture seeking a voice) was, therefore, something quite 
different from the subjectivity of women as conceived in Marxian approaches discussed earlier in this paper.

The Ehime group sought to create regional women's history that could build upon the initial sense of women as valid historical subjects as well as agents of history that Inoue Kiyoshi had codified in his 1949 book, and, at the same time, also texture this with ideas about history and ways to represent Ehime expressed in terms of the new metaphor of the 'chi' $i k i$ ' (region). The Circle recalled that they undertook the study of Inoue's Nihon Josei-shi 'very carefully and deeply' and sent their 'opinions directly to the author'. In fact, the study of the text lasted a full three years. By taking things very slowly and deliberately, members learnt how women's history had not yet come to terms with discrimination against women in Japan and how the educational system 'continued to rob women of their rights'. By arming themselves with this knowledge, moreover, they were able to realize the profound way in which learning and resistance might together provide a comprehensive and balanced way for participants to 'begin the process of regional [socio-political] change' (Ehime Josei-shi Sākuru 1978: 88).

Instead of merely lining up different regions of Japan within a linear sense of time (which would ultimately be referenced to Tokyo as the centre of Japan and 'modernity'), the Circle sought to bring to light the 'unique contradictions within regional society and the ways by which local groups might transform such conditions' (Ehime Josei-shi Sākuru 1978: 88). Through readings of Inoue Kiyoshi and Marxian history, involvement in the women's movement in Ehime, the serial publication of their own journal (Mugi), as well as the sponsoring of historical dramatizations in Matsuyama, the Circle sought to raise concrete awareness of problems in Ehime and how these might be linked to problems within other regions and social contexts in various parts of Japan.

It is important to stress again that in terms of both Marxian history and the writing of regional women's history, the Circle saw it as essential to look at the chi'iki (or 'region') not in terms of national revolution or 'class-based contradictions found in society and the state' (kokka shakai no kaikyūteki mujun). Instead, regional women's history would have to spotlight the problems 'specific to each chi'iki', starting from Ehime (Furuya 1978: 235). As contemporary member Yokogawa Setsuko has argued, regional women's history (chi' iki josei-shi) written first in Ehime was not a counterpart to Japanese women's history [Nihon josei-shi]' (Yokogawa 1995: 302-3) written either by Marxian historians or by the Tokyo Women's History Research Association. Neither was it a mere 
reproduction of the local women's history (kyojdo josei-shi) written in the city of Nagoya. Whilst influenced by Marxian approaches as well as by the Tokyo and Nagoya groups, women in Ehime conceived their own notion of the 'region' that could help women and other local residents become involved with regional, national and international politics in ways more gender inclusive (yet regionally specific) than Marxian approaches had imagined in their quest for national revolution and subjectivity during the 1950s. In terms of historical representation, then, post-war women had come 'full circle' from historiographical inclusion within Marxian views on the proletariat to the point where they were now writing their own local and regional histories in spaces apart from Marxian positions on subjectivity. These activities would subsequently pave the way for what is called the 'regional women's history' (chi'iki josei-shi) boom that was to take off from the late 1960s (Orii 2001).

Yet, this still leaves the question as to why these three groups appeared when they did and why these were the only major groups to emerge until the mid to late 1960s. There were a number of intersecting factors that no doubt assisted in the development of the groups examined. One important factor was the prototype or sponsoring organizations from which each of the groups in emerged: the Tokyo Women's History Research Association from the much larger Democratic Scientists Association, the Nagoya Women's History Research Association from the Asahi Women's History Circle, and the Ehime Women's History Circle from the Modern History Research Institute. The women who formed the groups studied were, in addition, locally active in women's movements and particularly interested in how new representations and discourses of history might be utilized for their own benefit. Perhaps most importantly, women from each of the three groups studied were personally and professionally acquainted with Marxian historians such as Inoue Kiyoshi, Ishimoda Shō and Matsumoto Shinpachirō. This combination of factors did help to bring about the dawning of local and regional women's history during the 1950s.

With hindsight, it would seem that there should have been more such groups popping up around Japan during the 1950s. There were, however, a number of problems that help explain why this would not take place for another decade. History writing as it was portrayed in the People's History Movement fell from favour by the mid-1950s, thus providing an incentive for more women to remain active within the more established field of the women's movement and mothers' movement rather than through the still gendered domain of history 
writing per se. Not until the mid-1960s would historical organizations and discourses even begin to acknowledge the existence of local and regional women's history. Moreover, the three groups taken up did not coordinate their activities or seek to cooperate with each other until the late 1960s. Yet, once the success of the Nagoya and Ehime groups became a matter of public knowledge around Japan from the mid-1960s, a wave of regional women's history-writing groups would begin to appear and subsequently build upon the initial gains made by local and regional women's history-writing groups. If there had been more cooperation and exchange among the three groups during the 1950s, it is likely that more such groups would have emerged and perhaps this 'wave' would have broken on to the historical landscape much earlier than the late 1960s.

\section{Conclusion}

Although Marxian historians did not fully recognize women as sociopolitical subjects within narratives that deviated from their approaches, they did offer new ways of thinking about and writing history that opened the door to women. In terms of methodology, women's groups picked up the Marxian idea of making history an 'existential tool' by which to seek socio-political change. They did, however, take exception to the presumption that this could only be done through the national subjectivity of class consciousness and instead sought to utilize history writing in the direction of subjectivity for women and others based upon the activities of individual women and the cooperation of women across class lines. ${ }^{24}$ Likewise, women interested in writing history also picked up the basic principles of history as they were developed in Marxian approaches, especially the concern with historical science and the history of everyday life. Indeed, the idea that history writing could become a scientific activity that would also help to change society and give people their own voices could not have come about without the efforts of Marxists to create new ideas about the relationship of history to socio-political change.

The influence of Marxian approaches upon women's history and local/regional women's history was therefore considerable. In terms of how each side envisioned the objectives of such practices there were, however, some striking differences. Whilst male historians in Tokyo looked to short-term structural change on the national level (e.g., the development of class consciousness for revolution and national subjectivity), women in Nagoya and Ehime hoped instead to create their own 
sense of subjectivity within local and regional society. This infusion of the local/regional dynamic into gender concerns, moreover, helped make possible the wider development of local and regional women's history so that it did not have to stop in Nagoya or Ehime but could eventually begin to thrive during the high-growth period from the late1960s. In these respects, it is fair to say that without Marxian approaches - and their imperfections - the historical landscape of post-war Japan would have been something completely different and far less interesting.

Curtis Anderson Gayle is a Ph.D. candidate in the Research School of Pacific and Asian Studies at The Australian National University.

\section{NOTES}

1 One general example can be found in twentieth-century fascism in Italy, Germany and Japan. Right-wing nationalism in pre-war Japan has been treated in Brown (1955).

2 See Forman 1998.

3 Ishimoda was a historian of pre-modern Japan, while Uehara specializes in premodern Europe, Tōyama in modern Japan, Inoue in modern Japanese politics and Matsumoto in pre-modern Japan. For more detailed information of the writings and views of these historians beyond the question of 'subjectivity', see Gayle (2003).

4 Originally founded in 1932, the Society regrouped in 1946 and began reissuing its journal, Rekishigaku Kenkyū. The principles for a new rekishigaku can be found in Rekishigaku Kenkyūkai (1946: 47).

5 Following the pre-war Kōza-ha, the Marxian historians examined in this paper originally set out the idea of a 'two-stage approach' to revolution in Japan - first a bourgeois democratic revolution and then the transition to socialism. During the late 1940s and early 1950s, however, this position would be modified to a one-stage (direct) transition to socialism as a result of ideological and geo-political challenges to Japanese Marxism.

6 The Democratic Scientists Association, Minshushugi Kagakusha Kyōkai, was conceived in 1945 in order to establish a new foundation for 'democratic science' in post-war Japan. The Marxian historians discussed in this paper belonged to both the Historical Science Society and the Democratic Scientists Association, and there was indeed much overlap and cross membership between these.

7 Kurahara was an important Marxian thinker and activist during both the pre-war and post-war periods and his pre-war ideas on 'culture' and political change in Japan were to an extent influenced by the Italian communist thinker Antonio Gramsci, as will be noted further along in the text.

8 This notion of 'reactionary' vs. 'revolutionary' culture in Japan can be found in more developed form in Matsumoto (1956: 167-209).

9 In addition, this can be found in Okamoto (1949: 2-18).

10 See also Kojima (1976).

11 Stalin (1950) argued that the ethnic 'nation' was something pre-dating capitalism, even though its evolution - in particular the 'germ' (hōga) of the nation - developed 
over centuries and, indeed, millennia. See also Ishimoda (1952). 'Bourgeois' and 'progressive' nationalisms are taken up and contrasted in Eguchi (1950).

12 The notion of the 'nation' as something 'transparent' and part of 'everyday life' has been taken up in works such as Billig (1995).

13 Assumptions of Japan's historical and social 'homogeneity' can be found in Tōma (1954).

14 The phrase 'shakaishugi kokka' (socialist state) was often used within Marxian history during this period. It was, needless to say, something quite different from the interwar notion of 'socialism in one country' propounded by 'converts' from Marxism to imperial ideology such as Sano Manabu. See Backmann and Okubo (1969).

15 Although American and European influence were held suspect, some Marxian historians such as Uehara Senroku and Munakata Seiya also included 'non-Asian' powers such as the Soviet Union within this constellation of hegemonic entities in the world system against which Japan and other Asian nations would have to resist.

16 Other sources of reference on the 'self-criticism' of Marxian historians during the late 1950s as to their earlier approaches to the 'national question' in Japan include: Nihon Kyōsantō (1982: 142-43).

17 The People's History Movement is also discussed in Tōyama (1968: 117) and Rekishigaku Kenkyūkai Gendaishibukai (1978: 76).

18 These points were confirmed to the author in Itō (2003), Ehime Josei-shi Sākuru (2003) and Nagahara (2003).

19 Murata had worked at the Historical Documents editing section of the University of Tokyo; Ide was an amateur historian in her own right; Mitsui was a descendant of the famous Mitsui Zaibatsu; and Nagahara was the wife of eminent Marxian historian Nagahara Keiji.

20 These ideas were originally expressed in the 1949 conference of the Historical Science Society, which focused upon the laws of history from a Marxian perspective. See Rekishigaku Kenkyūkai (1949).

21 The Modern History Institute, or Kindaishi Bunko, was founded in 1953 by the Ehime-born historian Shinozaki Masaru. Not only was the Institute instrumental in helping the Circle get off the ground, but Shinozaki himself served as advisor to the group and many of its meetings were held at the Institute.

22 Kawamata had belonged to a local teachers' union in Matsuyama at the time the Circle was created and continues to be active in the Circle to this very day.

23 Kumito was a young high school teacher in Matsuyama when she joined the Circle in 1956.

24 Since their objective was not state or system-wide revolution per se, local and regional women's history-writing groups did not immerse themselves within the Kōza-ha or Rōnō-ha debate. It will be recalled from earlier in the paper that Kōza-ha Marxists had formerly held that a two-stage approach to revolution in Japan was necessary, but that they modified this in 1950 to fit the idea of the immediate and direct transition to socialism that was being urged by the Comintern critique of Japanese capitalism. In contradistinction, women's history-writing groups were more interested in local and regional change that did not necessarily have to take place within the frame of reference about revolution that was the centrepiece of this famous debate. 


\section{REFERENCES}

Backmann, George M. and Genji Okubo 1969. The Japanese Communist Party, 19221945. Stanford: Stanford University Press.

Bandō, Hiroshi 1976. 'Rekishi ni okeru Minzoku no Mondai ni tsuite' [On the 'National Question' in History]. In Bandō Hiroshi (ed.), Minzoku no Mondai [The National Question] Vol. 15. Tokyo: Azekura Shobō: 290-328.

Billig, Michael 1995. Banal Nationalism. London: Sage Publications.

Brown, Delmer 1955. Nationalism in Japan: An Introductory Historical Analysis. Berkeley and London: University of California Press.

Eguchi, Bokurō 1950. 'Rekishi ni okeru Nashonarizumu no Hatten' [The Development of Nationalism in History]. Chūō Kōron [Foreign Affairs] 742: 46-53.

-1957. 'Shakaishugi to Minzokushugi' [Socialism and Nationalism]. Chūō Kōron, special edition: 91-101.

-1974. 'Rekishi ni okeru Kindaishugi no Hihan' [The Critique of Modernity in History]. In Eguchi Bokurō, Eguchi Bokurō Chosakushū [Selected Works of Eguchi Bokurō], Vol. 1. Tokyo: Aoki Shoten: 144-63.

Ehime Josei-shi Sākuru 1978. 'Rekishi wo Tsukuri, Manabi, Kiroku shita Nijūsan Nen' [33 Years of Making, Learning, and Recording History]. Rekishi Hyōron [Historical Critique] 335: 86-96.

-1986. Josei-shi Sākuru 30 Nen no Ayumi: Mugi no Ho ni Aoki Kaze Fuku [30 Years of the Ehime Women's History Circle]. Matsuyama: Ehime Josei-shi Sākuru.

-2003. Interview conducted with members of the Ehime Josei-shi Sākuru in Matsuyama, 21 July.

Figal, Gerald 1996. 'How to Jibunshi: Making and Marketing Self-Histories of Shōwa among the Masses in Postwar Japan'. The Journal of Asian Studies 55(4): 902-33.

Forman, Michael 1998. Nationalism and the International Labor Movement: The Idea of the Nation in Socialist and Anarchist Theory. University Park, PA.: Pennsylvania State University Press.

Furuya Naoyasu 1978. 'Kindaishi Bunko no Ayumi to Chi'iki Shakai Shiron' [The Development of the Institute for Modern History and the Theory of Regional History]. In Jichi Mondai Kenkyūjo (ed.), Chi' iki to Jichitai [Region and Autonomous Regions]. Tokyo: Jichitai Kenkyūsha: 232-45.

Gayle, Curtis Anderson 2003. Marxist History and Postwar Japanese Nationalism. London and New York: RoutledgeCurzon.

Germer, Andrea 2003. 'Feminist History in Japan: National and International Perspectives'. In Intersections: Gender, History and Culture in the Asian Context 9:1-20.

Gluck, Carol 1995. 'Sengoshi no Metahisutorī' [Post-war Japanese Meta-history]. In Yasumaru Yoshio (ed.), Nihon Tsüshi [The General Narrative of Japanese History]. Vol. 1: Rekishi Ishiki no Genzai [The Present Condition of Historical Consciousness]. Tokyo: Iwanami Shoten: 3-43.

Ichikawa, Yonehiko 1949. 'Minshushugi no Rekishiteki Hatten' [The Historical Development of Democracy]. Rekishigaku Kenkyū [Research in Historical Studies] 139: 24-35.

Ide, Fumiko 1976. 'Minshushugi Kagakusha Kyōkai Fujin Mondai Kenkyūkai: Watakushi to no Kakawari' [My Role in the Tokyo Women's History Research Association]. In Shisō no Kagaku Kenkyūkai (ed.), Kyōdō Kenkyū: Shūdan [Joint Research on Group Phenomena]. Tokyo: Heibonsha 1976: 111-17.

-1986. 'Sengo Fujin Mondai Kenkyū Koto Hajime' [Beginning with the Post-war Tokyo Women's History Research Association]. In Onnatachi no Genzai wo Tou Kai (ed.), Chosen Sengo/Gyakku Kōsu no Naka no Onnatachi [Women in the Reverse Course and Korean War]. Tokyo: Inpakuto Shuppankai: 148-57. 
Rekishigaku Kenkyūkai 1946. 'Rekishigaki Kōryō' [New Principles for the Study of History]. Rekishigaku Kenkyū 122: 47.

- 1949. Sekaishi no Kihon Hōsoku: 1949 Nendo Rekishigaku Kenkyūkai Taikai Hōkoku [The Basic Principles of World History]. Tokyo: Iwanami Shoten.

- (ed.) 1993. Sengo Rekishigaku to Rekiken no Ayumi: Sōritsu 60 Shūnen Kinen [60 Years of the Historical Science Society]. Tokyo: Aoki Shoten.

Rekishigaku Kenkyūkai Gendaishibukai 1978. Nihon no Gendaishi no Shuppatsu: Sengo Minshushugi no Keisei [The Start of Modern History in Japan and the Development of Post-war Democracy]. Tokyo: Aoki Shoten.

Saitō, Akio 1953. 'Minzoku Bunka Sōzō no Katei' [The Process of Creating National Culture]. In Rekishigaku Kenkyūkai (ed.), Minzoku no Bunka ni tsuite: Rekishigaku Kenkyūkai 1952 Nendo Taikai Hōkoku [On National Culture]. Tokyo: Iwanami Shoten: 138-43.

Stalin, Joseph 1935. Marxism and the National and Colonial Question. New York: International Publishers.

-1950. Concerning Marxism in Linguistics. Moscow: Pravda.

Tatewaki Sadayo 1957. Nihon no Fujin [Japanese Women]. Tokyo: Iwanami Shoten.

Tōma, Seita 1954. Nihon Minzoku no Keisei [The Formation of the Japanese Nation]. Tokyo: Iwanami Shoten.

Tōyama, Shigeki 1968. Sengo no Rekishigaku to Rekishi Ishiki [The Post-war Study of History and Historical Consciousness]. Tokyo: Iwanami Shoten.

-1976. 'Futatsu no Nashonarizumu no Taikō' [The Conflict between two Nationalisms]. In Bandō Hiroshi (ed.), Minzoku no Mondai [The National Question], Vol. 15: Rekishi Kagaku Taikei. Tokyo: Azekura Shobō: 114-21.

Tsuchiya, Takao 1946. 'Nihonshi Saiken no Gutaiteki Hōshin' [Basic Policy for the Reconstruction of Japanese History]. Sekai [The World] 4: 55-66.

Uehara Senroku and Munakata Seiya 1952. Nihonjin no Sōzō [Imagining the Japanese]. Tokyo: Tōyō Shokan.

Yokogawa Setsuko 1995. 'Chi'iki shakai josei-shi no Kaitaku - Chi'iki Shakai Shiron (Ehime) no Kanten kara' [Regional Women's History from the Perspective of Ehime]. In Yasumaru Yoshio (ed.), Nihon Tsūshi, Vol. 2. Tokyo: Iwanami Shoten: 295-308. 
Inoue, Kiyoshi 1949. Nihon Joseishi [The History of Japanese Women]. Tokyo: San'ichi Shobō.

Ishimoda, Shō 1952. Rekishi to Minzoku no Hakken [The Discovery of History and the Nation] 2 vols. Tokyo: Tokyo Daigaku Shuppankai.

-1990. Ishimoda Shō Chosakushū [The Selected Works of Ishimoda Shō] Vol. 14. Tokyo: Iwanami Shoten.

Itō Yasuko 1995. 'Josei ni totte no Sengo Gojūnen' [50 Years of the Post-war through Women]. Rekishi Hyōron 545: 45-58.

-2003. Interview conducted with Itō Yasuko of the Nagoya Josei-shi Kenkyukai, 25 July.

Koike, Kazuko 1981. 'Tatewaki Sadayo Shōron' [On Tatewaki Sadayo]. Rekishi Hyōron 380: 97-107.

Kojima, Tsunehisa 1976. Nihon Shihonshugi Ronsō [Debates on Japanese Capitalism]. Tokyo: Ariesu Shobō.

Kurahara, Korehito 1948. 'Bunka Katsudō ni saishite' [On Cultural Activism]. Zen'ei [Vanguard] 26: 62-73.

Maruyama, Masao 1964. 'Nihon ni okeru Nashonarizumu' [Nationalism in Japan]. In Maruyama Masao, Gendai Seiji no Shisō to Kōdō [Thought and Behavior in Japanese Politics]. Tokyo: Miraisha : 152-70.

-1976. 'Kuga Katsunan-Hito to Shisō' [Kuga Katsunan and his Thoughts]. In Maruyama Masao, Senchū to Sengo no Aida [Between the War and Post-war]. Tokyo: Misuzu Shobō: 281-96.

Matsumoto, Shinpachirō 1956. 'Kakumeiteki Dentō ni tsuite' [On Revolutionary Cultural Traditions]. In Tōma Seita et al. (eds), Kōza Rekishi [Symposium on History] Vol. 4. Tokyo: Otsuki Shoten: 167-209.

Mitsui, Reiko 1959. 'Joseishi Kenkyūkai Guruppu' [The Tokyo Women's History Research Association]. In Fujin Gahō [Portraits of Women] 9: 183-87.

Murata Shizuko 1969. 'Shohyō: Nagoya Josei-shi Kenkyūkai "Hahaoya Jidai-Aichi no Josei-shi"' [Book Review: The Nagoya Women's History Research Association's 'A Time for Mothers: History in Aichi Prefecture]. Rekishi Hyōron 230: 44.

Nagahara, Kazuko 2003. Interview conducted with Nagahara Kazuko of the Tokyo Josei-shi Kenkyūkai at Tokyo Women's Plaza, 12 July.

Nagoya Josei-shi Kenkyūkai (ed.) 1969. Haha no Jidai: Aichi no Josei-shi [A Time for Mothers: History in Aichi Prefecture]. Nagoya: Fubaisha.

Nakayama Yasuko 1966. 'Tokushu: Kindai Josei-shi, Nagoya Josei-shi Kenkyūkai' [Special Issue on Modern Women's History and the Nagoya Women's History Research Association]. Rekishi Hyōron 195: 89-91.

-1992. Okotoba wo Kaesu you desu ga [Talking Back]. Nagoya: Chūō Shuppan.

Napier, J. P. 1952. A Survey of the Japan Communist Party. Tokyo: The Nippon Times Ltd.

Nihon Kyōsantō 1982. Nihon Kyōsantō no Rokujūnen [60 Years of the Japanese Communist Party]. Tokyo: Nihon Kyōsantō Chūō Iinkai Shuppankyoku.

Oguma, Eiji 2002. Minshu to Aikoku: Sengo Nihon no Nashonarizumu to Kokyōsei [Democracy and Patriotism: Post-war Japanese Nationalism and the Public Sphere]. Tokyo: Shinyōsha.

Okamoto, Saburō 1949. 'Kōnichi Minzoku Tōitsu Sensen no Keisei Katei' [The Formation of the Japanese Front against China]. Rekishigaku Kenkyū 138: 2-18.

Orii Miyako 2001. Chi'iki Josei-shi Nyūmon [An Introduction to Regional Women's History]. Tokyo: Domesu Shuppan.

Pozzolini, Alberto 1970. Antonio Gramsci: An Introduction to His Thought, trans. Anne F. Showstack. London: Pluto Press. 